\title{
MODERN SURGICAL TREATMENT OF RECTAL CANCER
}

\author{
Mario Zovak ${ }^{1,23}$, Zdenko Bilić ${ }^{1}$, Mario Kopljar ${ }^{1,3}$ \\ ${ }^{1}$ Department of Surgery, University Hospital Center "Sestre milosrdnice“, Zagreb, \\ Croatia; ${ }^{2}$ Medical Faculty, University of Zagreb, Zagreb, Croatia; ${ }^{3}$ Medical Faculty \\ Osijek, Josip Juraj Strossmayer University, Osijek, Croatia
}

\begin{abstract}
Summary
Surgical treatment is a method of choice in treating patients with resectable primary form of rectal cancer. An important step in treatment is the multidisciplinary approach from different medical specialties in the fields of radiology, gastroenterology, oncology and surgery. In recent years, several minimally invasive surgical procedures have been developed that improve postoperative recovery while still preserving oncological principles, such as laparoscopic low anterior resection, transanal total mesorectal excision and robotic surgery. Surgical and oncological principles that must be respected in all cases are wide resection of the tumor with histologically free resection margins and the use of total mesorectal excision with anal sphincter preservation and preservation of the continuity of the intestine whenever possible.
\end{abstract}

Keywords: rectal neoplasms/surgery; laparoscopic surgery; robotic surgery; surgical onco$\log y$.

\section{INTRODUCTION}

Surgical treatment is a method of choice in treating patients with resectable primary form of rectal cancer. It should be noted that in the planning of treatment for all patients, an important step is the multidisciplinary approach from different medical specialties in the fields of radiology, gastroenterology, oncology and surgery. In all patients diagnosed with rectal cancer it is necessary to perform a thorough preoperative diagnostic workup to help accurately determine the stage, i.e. the spread of the malignant disease. Depending on the stage of the disease, surgical treatment may thereby be the only form of treatment or one modality in combination with adjuvant or neoadjuvant chemotherapy and radiotherapy.

The primary objective of the surgical treatment of rectal cancer is radical wide resection of the tumor with histologically free resection margins that can be achie- 
ved by the use of total mesorectal excision (TME) [1,2]. The second goal is the preservation of the anal sphincter and ensuring the continuity of the intestine whenever possible $[3,4)$. Operating procedures for the treatment of rectal cancer in addition to the usual surgical and oncologic principles have their own peculiarities and due to the specific anatomical relationship of the rectum within the limited pelvic space, especially extra peritoneal part of the rectum, as the formation of intestinal anastomosis seems very sensitive and demanding process [5].

For patients suffering from rectal cancer the choice of optimal surgical procedure depends on many factors, such as the distance of the tumor from the anal verge (low, medium and high rectal tumors), the dimensions of the tumor, histological differentiation of the tumor, signs of tumor invasion in the lateral wall of the pelvis or infiltration of pelvic organs, the presence of regional lymph node metastases, general condition of the patient, preoperative anorectal sphincter function and individual specificities of the pelvic anatomy of the patient [6].

Bearing in mind all mentioned above, rectal cancer can be surgically treated with local excision or radical resection of the tumor. Local excision of the tumor can be performed transanally and generally does not disturb defecation. Radical resection involves either transabdominal approach with colorectal anastomosis, thereby preserving the natural way of defecation, and such procedures are called sphinctersaving procedures. If radical surgery cannot be performed with sphincter preservation, abdominoperineal extirpation of the rectum is performed with the formation of a permanent colostomy.

\section{TECHNIQUES OF LOCAL EXCISION}

Local excision of tumors of the rectum is the method of choice for those patients suffering from early forms of rectal cancer of low malignant potential, as well as for those patients suffering from advanced forms of the disease, and where their deteriorated general condition precludes the possibility to perform radical surgery. Because of the higher risk for recurrence of disease compared with radical operating procedures, before planned local excision of rectal cancer diagnostic methods must met all of these criteria: Superficial Tis and T1 rectal cancer, with no signs of fixation of tumor to the surface, diameter less than $3 \mathrm{~cm}$, with the involvement of less than $30 \%$ of the circumference of the hose, favorable histological postoperative findings, the possibility of achieving free resection margins, without radiological signs of disease, good compliance and readiness for intensive postoperative monitoring [7].

Techniques of local excision are transanal excision (TAE) and transanal endoscopic surgery (TES). Transanal endoscopic surgery means more modern surgical 
techniques where transanal access to low-lying tumors of the rectum is achieved by indirect optical system, and with specially designed surgical instruments. In comparison with conventional transanal excision, transanal endoscopic surgery provides better visualization and access, and is associated with a lower incidence of local recurrence of the disease. The surgical techniques of transanal endoscopic surgery include: transanal endoscopic microsurgery (TEM), transanal endoscopic operations (TEO) and transanal minimally-invasive surgery (TAMIS) [8-10].

\section{RADICAL (transabdominal) OPERATING PROCEDURES}

The radical surgical procedures for the treatment of rectal cancer include sphincter-preserving operations and abdominoperineal extirpation of the rectum. These radical surgical methods include not only the resection of the primary rectal tumor itself, but also provide adequate lymphadenectomy to remove all potential sites of lymphatic drainage and metastases [11].

When performing surgical procedures in the treatment of rectal cancer all the principles of surgical resection should be respected, as follows: histologically negative resection margins of the rectum (proximal margin of at least $5 \mathrm{~cm}$ and distal margin of at least 1-2 cm for sphincter-preserving surgical procedures with radial margin ensuring at least $1 \mathrm{~mm}$ distance from the edge of the tumor to the mesorectal fascia), total mesorectal excision (TME), dissection of regional lymph nodes and preserving anorectal sphincter functions. One of the most dynamic and the most controversial areas of discussion related to surgical resection of the rectum is a question of oncologically safe distal margin.

Total mesorectal excision (TME) is now standard surgical technique first introduced in 1982 to be used in surgical procedures of anterior resection of the rectum and abdominoperineal extirpation of the rectum. This technique uses avascular zone between the mesorectal fascia and surrounding parietal fascia and completely removes perirectal fat with associated lymph nodes, thus significantly reducing the ability of local disease recurrence. Standard TME is performed conventionally (through open surgery), laparoscopically, and more recently by the application of robotic-assisted technology. Today, experienced surgical centers perform total mesorectal excision also through transanal approach (Transanal total Mesorectal Excision, TATME), especially for distal rectal cancer, in obese patients and in patients with narrow pelvis [12].

Sphincter-preserving surgical procedures are the method of choice for those patients who do not meet the conditions for local excision of the tumor, and meet all of the following criteria: T2-T4 rectal cancer resection negative distal margin of at least 
1-2 $\mathrm{cm}$ and preserved sphincter anorectal function. Most frequently used sphincterpreserving operation today is the anterior resection of the rectum, which can be a high, low or ultra-low resection according to the localization of the tumor (distance from the anal verge) [6). The surgery involves total or partial resection of the rectum and the sigmoid portion of the colon where colorectal or coloanal anastomosis is formed between the descending part of the colon or rectum and anus. Today, with the use of various forms of stapling devices (staplers), the formation of intestinal anastomosis is technically more feasible and safer, especially in the formation of low coloanal anastomosis [13,14].

Abdominoperineal extirpation of the rectum has previously been the gold standard in the surgical treatment of low rectal cancer. The development of surgical techniques, stapling devices (staplers) and wide application of neoadjuvant chemotherapy and radiotherapy, this surgical procedure is increasingly giving way to previously described sphincter-preserving surgical procedures. However, it still serves as the method of choice for all patients diagnosed with T2-T4 rectal cancer where it is not possible to achieve tumor free distal margin of at least $1-2 \mathrm{~cm}$, with locally advanced rectal cancer and low infiltration of the sphincter mechanism and / or rectovaginal septum, as well as those patients with poor preoperative function of the sphincter mechanism [15]. Abdominoperineal extirpation removes the rectum with tumor and anus (including total mesorectal excision and sphincter mechani$\mathrm{sm})$, and part of sigmoid colon, with the formation of a permanent terminal colostomy.

\section{PALLIATIVE SURGICAL PROCEDURES}

For patients diagnosed with inoperable cancer of the rectum and signs of disseminated malignant disease, the goal of surgery is to reduce symptoms that include low obstruction (ileus) or control the bleeding from the tumor. Up to $20 \%$ of patients with advanced-stage colorectal cancer present as emergencies [16]. For these patients, palliative procedures such as endoluminal stenting, forming a colostomy or non-surgical procedures such as cryotherapy, electrosurgery and laser photocoagulation of tumor tissue may be used.

\section{LAPAROSCOPIC SURGERY AND ROBOTIC-ASSISTED TECHNOLOGY IN THE SURGICAL TREATMENT OF RECTAL CANCER}

Radical (transabdominal) surgery of rectal cancer today can be performed as open surgery, laparoscopically and by the application of robotic-assisted techno- 
logy [17-19]. With the development of endoscopic and robotic-assisted technology, the open surgical technique for rectal cancer is increasingly giving way to these new surgical approaches. Laparoscopic approach to the operation carries with it some of the previously recognized advantages such as faster postoperative recovery of patients, shorter hospital stay, less incidence of postoperative complications, reduced need for blood transfusions, aesthetically acceptable postoperative scar and lower incidence of development of postoperative adhesions and intestinal obstruction. There are also disadvantages of this approach, such as much longer learning curve for surgeons, higher cost and often lower availability of surgical equipment, as well as restrictions on the laparoscopic approach conditioned by the patient itself (e.g. morbid obesity, heavy intraabdominal adhesions) [20]. In past years, laparoscopic rectal surgery was compared with conventional rectal surgery in many international randomized studies (eg. COLOR II, Corean, ACOSOG 6051, Alacarte) that produced conflicting results and no clear position on the possible superiority of laparoscopic surgery in the treatment of rectal cancer. Therefore, it should be noted that the choice of surgical approach should be determined primarily by taking into account individual patient characteristics, tumor characteristics and experience of the surgeon and the surgical team.

Robotic-assisted surgery represents the latest technological advancement that combines the advantages of the laparoscopic approach with the benefits of open (classic) surgical approach. Robotic-assisted surgery was developed to overcome the limitations of minimally invasive surgery and to expand the possibilities for the surgeon in performing open surgery [17]. In addition, the procedures can be performed directly through the remote operation or computer control. Using computer management mode enables the remote surgery, which is one of the main advantages of this new technology.

It should be noted that for all surgical techniques, regardless of them being open surgeries, laparoscopic or robotic-assisted procedures, there are the same surgical and oncological principles which are wide resection of the tumor with histologically free resection margins and the use of total mesorectal excision with anal sphincter preservation and preservation of the continuity of the intestine whenever possible.

\section{References}

[1] Heald RJ, Husband EM, Ryall RD. The mesorectum in rectal cancer surgery--the clue to pelvic recurrence? Br J Surg. 1982;69(10):613-6.

[2] Heald RJ. The 'Holy Plane' of rectal surgery. J R Soc Med. 1988;81(9):503-8.

[3] Heald R. Surgery in rectal cancer: a staple in time saves a stoma. Nurs Mirror. 1980;150(1):30-2. 
[4] Heald RJ, Leicester RJ. The low stapled anastomosis. Dis Colon Rectum. 1981;24(6):43744.

[5] Stelzner S, Holm T, Moran BJ, Heald RJ, Witzigmann H, Zorenkov D, et al. Deep pelvic anatomy revisited for a description of crucial steps in extralevator abdominoperineal excision for rectal cancer. Dis Colon Rectum. 2011;54(8):947-57.

[6] Salerno G, Sinnatamby C, Branagan G, Daniels IR, Heald RJ, Moran BJ. Defining the rectum: surgically, radiologically and anatomically. Colorectal Dis. 2006;8 Suppl 3:5-9.

[7] Robinson C, Artinyan A. Pushing the Limits of Local Excision for Rectal Cancer: Transanal Minimally Invasive Surgery (TAMIS) for Rectal Cancer Using the Port-in-Port Technique. Ann Surg Oncol. 2016;23(3):918.

[8] Slater A, Betts M, Anderson EM, Cunningham C. Transanal endoscopic microsurgery for rectal cancer. Clin Radiol. 2016;71(2):e121-9.

[9] Verseveld M, Barendse RM, Gosselink MP, Verhoef C, de Graaf EJ, Doornebosch PG. Transanal minimally invasive surgery: impact on quality of life and functional outcome. Surg Endosc. 2016;30(3):1184-7.

[10] Keller DS, Haas EM. Transanal Minimally Invasive Surgery: State of the Art. J Gastrointest Surg. 2016;20(2):463-9.

[11] Horzic M, Kopljar M. Minimal number of lymph nodes that need to be examined for adequate staging of colorectal cancer--factors influencing lymph node harvest. Hepatogastroenterology. 2005;52(61):86-9.

[12] Heald RJ. A new solution to some old problems: transanal TME. Tech Coloproctol. 2013;17(3):257-8.

[13] Moran B, Heald R. Anastomotic leakage after colorectal anastomosis. Semin Surg Oncol. 2000;18(3):244-8.

[14] Heald RJ. Towards fewer colostomies--the impact of circular stapling devices on the surgery of rectal cancer in a district hospital. Br J Surg. 1980;67(3):198-200.

[15] Mukkai Krishnamurty D, Wise PE. Importance of surgical margins in rectal cancer. J Surg Oncol. 2016;113(3):323-32.

[16] Brent A, Armstrong T, Nash GF, Heald RJ. Therapeutic use of the Heald Silastic Anal Stent. Colorectal Dis. 2007;9(3):279-80.

[17] Chand M, Heald RJ, Parvaiz A. Robotic total mesorectal excision - precision surgery with even more precise tools. J R Soc Med. 2016;109(2):78-9.

[18] Tou S, Bergamaschi R, Heald RJ, Parvaiz A. Structured training in robotic colorectal surgery. Colorectal Dis. 2015;17(3):185.

[19] Chand M, Heald RJ. Laparoscopic rectal cancer surgery. Br J Surg. 2011;98(2):166-7.

[20] Heald RJ. Commentary: Rectal cancer patients are often not suitable for laparoscopic surgery. Colorectal Dis. 2010;12(1):31-2. 


\section{Sažetak}

\section{Suvremeno kirurško liječenje raka rektuma}

Kirurgija je metoda izbora u liječenju bolesnika s resektabilnim rakom rektuma. Važan korak u liječenju je multidisciplinarni pristup različitih medicinskih specijalnosti iz područja radiologije, gastroenterologije, onkologije i kirurgije. U posljednjih nekoliko godina razvijeno je nekoliko minimalno invazivnih kirurških postupaka s ciljem poboljšanja postoperativnog oporavka uz očuvanje svih onkoloških principa, kao što su laparoskopske niske prednje resekcije, transanalne totalne mezorektalne resekcije i robotske operacije. Kirurška i onkološka načela koja se moraju poštivati u svim slučajevima su široka resekcija tumora s histološki slobodnim resekcijskim rubovima i totalna mezorektalna ekscizija s očuvanjem analnog sfinktera kao i očuvanje kontinuiteta crijeva kad god je to moguće.

Ključne riječi: novotvorine rektuma/kirurško liječenje; laparoskopska kirurgija; robotska kirurgija; kirurška onkologija.

Corresponding author:

Mario Zovak

e-mail: mario.zovak@kbcsm.hr 
